\title{
remeraldinsight
}

\section{Tourism Review}

Factors affecting employees' job embeddedness in the Egyptian airline industry

Yasser Moustafa Shehawy, Ahmed Elbaz, Gomaa M. Agag,

\section{Article information:}

To cite this document:

Yasser Moustafa Shehawy, Ahmed Elbaz, Gomaa M. Agag, (2018) "Factors affecting employees' job embeddedness in the Egyptian airline industry", Tourism Review, https://doi.org/10.1108/TR-03-2018-0036

Permanent link to this document:

https://doi.org/10.1108/TR-03-2018-0036

Downloaded on: 08 October 2018, At: 06:14 (PT)

References: this document contains references to 121 other documents.

To copy this document: permissions@emeraldinsight.com

Access to this document was granted through an Emerald subscription provided by emerald-srm: 178665 []

\section{For Authors}

If you would like to write for this, or any other Emerald publication, then please use our Emerald for Authors service information about how to choose which publication to write for and submission guidelines are available for all. Please visit www. emeraldinsight. com/ authors for more information.

\section{About Emerald www.emeraldinsight.com}

Emerald is a global publisher linking research and practice to the benefit of society. The company manages a portfolio of more than 290 journals and over 2,350 books and book series volumes, as well as providing an extensive range of online products and additional customer resources and services.

Emerald is both COUNTER 4 and TRANSFER compliant. The organization is a partner of the Committee on Publication Ethics (COPE) and also works with Portico and the LOCKSS initiative for digital archive preservation.

*Related content and download information correct at time of download. 


\title{
Factors affecting employees' job embeddedness in the Egyptian airline industry
}

\author{
Yasser Moustafa Shehawy, Ahmed Elbaz and Gomaa M. Agag
}

\begin{abstract}
Purpose - The importance of employees' job embeddedness perception in the airline companies has not been given the required attention. To recognise the role of frontline employees' perception regarding job embeddedness, the present research aims to develop and investigate a model that examines the determinants and consequences of employees' job embeddedness in airline industry. The current study also aims to enrich the literature on human resources in the fields of transportation service management as the lifeblood of tourism industry as a related service industry by providing a comprehensive framework and measurement scale regarding the social exchange theory.
\end{abstract}

Design/methodology/approach - The study used a survey among a sample representative of frontline employees operating in Egyptian airline industry across Egypt. In total, 870 questionnaires were collected and analysed using structural equation modelling using WarpPLS 6.0.

Findings - The results indicate that both supervisors' support and employees' advocacy have a significant effect on job embeddedness. In addition, it found out that job embeddedness has a significant effect on organisational commitment and employees' intention to leave.

Research limitations/implications - This paper is conceptual in nature regarding the social exchange theory in service related industries such as airlines and tourism.

Practical implications - The authors intend to use these considerations as a basis for future research implications for tourism small- and medium-sized enterprises in the Middle-Eastern and North-African region.

Social implications - This paper contributes to the literature on social exchange theory by measuring factors affecting employees' job embeddedness in the Egyptian airline industry, notably its related human resources as a service industry.

Originality/value - This study developed and empirically tested a comprehensive model of job embeddedness with its drivers and evaluated its impact on both organisational commitment and intention to leave. Such findings hold important implications for tourism small- and medium-sized enterprises in the Middle-Eastern and North-African region.

Keywords Airline industry, Intention to leave, Supervisor support

Paper type Research paper

\section{Introduction}

The employee turnover intention has become a critical problem in the context of the airline industry in which human resources is considered the most significant factor (Anvari et al., 2013; McGinley et al., 2017). Recent studies conducted to discuss financial determinants of the employee turnover rate have pointed out to this problem (Waldman et al., 2004; Tziner and Birati, 1996; Simons and Hinkin, 2001; Hinken and Tracey, 2000). As voluntary turnover causes a wide array of considerable costs to organisations, they are continuously searching for new ways to retain their qualified employees. Regarding jobs paying under $\$ 50,000$ annually, the estimated voluntary leaving cost per employee amounts to about 20 per cent of the annual salary received by that employee (Lucas, 2012). Therefore, the employees'
Yasser Moustafa Shehawy is Associate Professor at the Department of Tourism Studies, Faculty of Tourism and Hotels, University of Sadat City, Sadat City, Egypt and Department of Tourism and Archeology, Faculty of Arts and Humanities, Jazan University, Abo-Arish, Saudi Arabia. Ahmed Elbaz is based at the Department of Tourism Studies, University of Sadat City, Sadat City, Egypt.

Gomaa M. Agag is based at the Nottingham Business School, Nottingham Trent University, Nottingham, UK and University of Sadat City, Sadat City, Egypt.
Received 9 March 2018 Revised 22 May 2018 16 June 2018

Accepted 19 June 2018 
turnover intentions should be handled at early stages, and managing human resources effectively is very crucial in this process (Hemdi and Nasurdin, 2006; Akgündüz and Sanli, 2017).

On the basis of the literature related to social exchange theory (SET), the supervision's support to employees has a positive influence on both attitudinal and behavioural outcomes of those employees. Akgündüz and Sanli (2017) investigated the impacts of supervisor-subordinate exchange on employees' job embeddedness in hotel context, while Liden and Graen (1980) studied the influences that supervisor-subordinate exchange causes on job satisfaction and performance in university context. Supervisors can not only be a provider of informational, social and emotional support through helping to avoid work stress or pressure (Himle et al., 1989), but also be considered as organisational mediators in actions towards their followers (Eisenberger et al., 2002). This support is essential in the airline industry as frontline employees encounter many different challenges. These challenges firstly include unbalanced, extended work hours and rigid work schedules (Karatepe, 2011); secondly, the obstacles exist around obtaining necessary information helping personnel grow and enhancing their job embeddedness (Zhou et al., 2003); thirdly, the need of employees for self-actualisation and satisfaction, which is influenced by the supervision's style (Øgaard et al., 2008). Furthermore, despite numerous factors may also affect employees' job embeddedness. It includes personal factors such as personality, gender, age, race and attitudes, as well as organisational factors such as values, culture and climate, fairness of policies and decentralisation (Meyer and Allen, 1997; Ilkhanizadeh and Karatepe, 2017). Some scholars argued that supervisors' support is considered an important predictor of both employees' feelings towards their supervisors and the behaviours they reflect (Akgündüz and Sanli, 2017).

The internal practices concerning communication and employees have positive effects on the employees' behaviours and the cooperation in many ways, which, in turn, raises the employees' advocacy perception (O'Fallon, 2014). The relationships between organisations and employees are based on a win-win concept, and they improve the employees' positive attitude towards their jobs and organisations (Shore and Tetrick, 1991; Yeh, 2014). The organisational practices related to employees' advocacy have become commonly widespread in organisations where employees are considered as valuable assets, while adopting them is becoming difficult in organisations in which employees are treated as "worthless" (Rynes, 2004).

The employees' job embeddedness increases when they perceive that their interests are accepted as valuable as the interests of the company, while their turnover intention decreases (Otaye and Wong, 2014; Akgündüz and Sanli, 2017). The purpose of the current study is to offer a holistic model for supervisors support, employees' advocacy, job embeddedness, organisational commitment and employees' intention to leave. The objectives of the study are as follows:

- to examine the effect of supervisors support on organisational commitment and job embeddedness;

- determine the effect of employees' advocacy on job embeddedness and intention to leave; and

- identify the effect of job embeddedness and organisational commitment on employees' intention to leave.

The present research seeks to analyse the factors that influence job embeddedness of employees in addition to the influence of employees' job embeddedness on both organisational commitment and intention to leave. This will be fulfilled by formulating and testing an integrated model, on the basis of contributions of well-founded theory; this is called the social exchange theory (SET; Blau, 1964). Accordingly, the current study aims to 
enrich the literature on human resources in the fields of transportation service management as the lifeblood of tourism and airline industry through the following:

- identifying the antecedents influencing job embeddedness of frontline employees in the airline companies; and

- investigating the effect of job embeddedness on both organisational commitment and intention to leave.

The research findings are expected to help managers of the airline companies to formulate appropriate strategies that support job embeddedness, consequently increasing organisational commitment of employees and decreasing their intentions to leave.

This research is structured as follows: the next section presents literature related to the research variables and theories in addition to the hypotheses development. After that, data collection methods and measurements have been demonstrated. Finally, the research findings, discussion and practical implications have been provided as well as indicating the research limitations and proposed future research.

\section{Literature review}

Established theory on voluntary turnover largely stems from the work of March and Simon (1958), who posited that perceived ease (i.e. the presence of job alternatives) and desirability (i.e. level of job satisfaction) of leaving one's job combine to predict intentions to leave. This model underpins the majority of the subsequent attitude-driven turnover research, with job satisfaction and organisational commitment being two of the most commonly operationalised variables (Hom and Griffeth, 1995; Mitchell et al., 2001; Robinson et al., 2014; Bos-Nehles and Meijerink, 2018). However, while there are significant results, the effects are also weak and many argue that not enough attention has been given to alternative explanations (Maertz and Campion, 1998; Robinson et al., 2014).

On the basis of SET, obligations emerge through interactions that take place between parties (Emerson, 1976; Bos-Nehles and Meijerink, 2018). These interactions are typically based on a counterpart's action (Blau, 1964). The governance dimensions such as responsibility, transparency, participation, structure, effectiveness and power should be considered in human resource management (Ruhanen et al., 2010). The social exchange relationships take place when managers take care of their employees, and, in turn, those employees display positive attitudes as well as effective work behaviours (Cropanzano and Mitchell, 2005; Karatepe, 2016). In addition, social exchange relationships proceed between two parties depending on a sequence of shared, despite not necessarily concurrent and exchanges, which produce a pattern of mutual responsibility from each party (Blau, 1964; Karatepe, 2016). Previous studies have indicated that an individual is involved in more than one social exchange relationship (at least two) at work including one with his/her direct supervisor, and another with the organisation at which he/she works (Masterson et al., 2000). The SET proposed by Blau (1964) forms the basic theoretical framework foundation on which the present study based and emphasises the vital role played by supervisors' support in improving the level of organisational commitment, job embeddedness and turnover intention of frontline employees in the airline companies. SET provides the foundation to realising the roles played by organisations, supervisors and employees in the relationships, the level of organisational commitment, as well as organisations' obligation to their employees' well-being (Kottke and Shafranski, 1988; Bentley et al., 2016). Studies linked between social exchanges relationships and supervisors' support (Kottke and Shafranski, 1988; Karatepe, 2016; Ferreira et al., 2017) emerged based on the notion stated that the benefits perceived by employees from their supervisors aligned with the input of those employees in the relationship. While supervisors provide their employees with necessary support needed, those employees feel more 
committed to achieve expected performance related to work, which, in turn, reflects positively on both job embeddedness and organisational commitment. Moreover, the positive relation between supervisors and subordinates has been found to improve the level of job embeddedness (Akgündüz and Sanli, 2017) and to reduce the level of turnover intention of employees (Roderick and Deery, 1997; Kang et al., 2015; Ferreira et al., 2017).

Employees in frontline service jobs with turnover intentions can seriously erode service delivery and complaint handling processes (Rathi et al., 2013; Afsar et al., 2018). With this realisation, it is important to retain a pool of talented frontline employees who can develop ideas for performance improvement and offer thorough solutions to customer problems/ complaints (Alonso and O'Neill, 2011; Slatten and Mehmetoglu, 2011; Karatepe, 2016). It is also important to hire talented frontline employees who fit the job and organisational culture (Dawson and Abbott, 2011; Karatepe, 2013). As a critical employee retention strategy, job embeddedness appears to enable managers to retain such employees as it focuses on why employees stay on their jobs rather than why they leave their jobs (Mitchell et al., 2001 Karatepe,2013; Karatepe, 2016; Ferreira et al., 2017). Turnover intention reflects withdrawal behaviour and conscious desire of an employee to leave an organisation within the near future (Harpert, 2013). According to Azanza et al. (2015), turnover intention is an individual's behaviour intention to leave the organisation. Khan (2015) further elaborated that turnover intention is the final cognitive decision-making process before an employee decides to leave a job. Researchers found that intention to leave has a direct causal influence on turnover decision (Rahman and Nas, 2013). Based on previous studies, turnover intention was found to be a strong precursor of actual employee turnover (Biron and Boon, 2013; Harhara et al., 2015; Haque et al., 2017).

The potential role of cultural influences on job embeddedness deserves further scrutiny. To our knowledge, only three studies (Hom et al., 2009; Ramesh and Gelfand, 2010; Tanova and Holtom, 2008) have been conducted on samples of non-US workers. Cultural differences may affect the generalizability of job embeddedness theory. In this paper, we take Egypt as an example to illustrate that there is cultural boundary to the theory of job embeddedness. We choose Egypt because the country has been found to own a distinct culture, which is different with the culture in the developed countries (Elbaz and Haddoud, 2017; Elbaz et al., 2018). According to Hofstede's cultural theory (Hofstede, 2001), national culture is composed of five main dimensions: power distance index, individualism, masculinity, uncertainty avoidance index and long-term orientation. Studies have shown that Egypt's national culture has major differences with the developed countries' national culture in two aspects: individualism (the following numbers depict how the countries score on individualism: Egypt, 38; the USA, 91; Hofstede and Hofstede, 2005, pp. 78-79) and power distance (Egypt, 80; the USA, 29; Hofstede and Hofstede, 2005, p. 211). Thus, Egypt provides a good example to test if the theory of job embeddedness can be generalised to other cultural settings.

\section{Theoretical foundation and hypothesis formulation}

The underlying premise of the model is that frontline employees with supervisor support and employees' advocacy are embedded in the job and, therefore, display organisational commitment and intention to leave. In technical terms, job embeddedness fully mediates the effects of supervisor support and employees advocacy on organisational commitment and intention to leave.

As mentioned by Burke (2003), both SET and Reciprocity Norm Theory (RNT) have been built on the basis that both employers and employees may be devoted to each other in an emotional manner. SET is based on the notion that people help each other even if they are not obliged to do, and in return, it's expected from other people to help in the future (Blau, 1964; Karatepe, 2016). In this context, it is argued that if employees highly perceive support from their organisation, they will reveal positive behaviours towards their organisations 
(Cropanzano and Mitchell, 2005; Karatepe, 2016; Ferreira et al., 2017). RNT contends that people feel responsibility towards individuals who help them and accordingly they respond (Gouldner, 1960). Hence, acquired organisational support is associated with employees' socio-emotional needs; this means that employees' performance and innovative are expected to be rewarded by the organisation (Burke, 2003; Martınez-Roman et al., 2015; Ferreira et al., 2017).

In context to that, several studies pointed out that there is a strong association between supervisors' support and affective organisational commitment (Eisenberger et al., 2001; Karatepe, 2016; Robinson et al., 2014) aligned with the function and meaning of work and the job (Morse and Weiss, 1955; Robinson et al., 2014). Wadhwa (2012) indicated that supervisors are not only providers of information but also affect their employees' perception regarding work climate in organisations. Supervisors who are not supportive are likely to be unsuccessful in communicating with their employees in an effective manner (Burke et al., 1992; Robinson et al., 2014; Akgündüz and Cin, 2015), which will likely reflect negatively on employees' commitment towards their organisations. Figure 1 shows our conceptual framework. The hypothesised relationships are discussed in the following section.

\section{Supervisors support, job embeddedness and organisational commitment}

In light of SET and RNT, the turnover intention of employees and their positive emotions towards their jobs and their organisations is positively affected if they perceive that the organisation adopts their needs. Furthermore, studies reveal that the concept "being embedded in work", which is related to why employees stay in their organisations, is also related to their turnover intention (Akgündüz and Cin, 2015; Takawira et al., 2014; Akgündüz and Sanli, 2017). Felps et al. (2009) examined the role of job embeddedness in a study where a hospitality sample was aggregated with other industries. Karatepe and Ngeche's (2012) study of front line hotel employees found that job embeddedness mediated employee engagement and job performance. Consistent with previous research in other contexts (Halbesleben and Wheeler, 2008; Ferreira et al., 2017), job embeddedness mediated turnover intentions and enhanced levels of job performance. In the only other hospitality-based study, Karatepe and Karadas (2012) found that job embeddedness mediated the relationship between empowerment and service recovery performance. At the level of empirical studies, it has been revealed that the employees' turnover intention is significantly correlated with their perception regarding organisational support (Pattie et al., 2006; Dawley et al., 2010; Ferreira et al., 2017; Robinson et al., 2014). Therefore, it can be concluded that employees who have a high degree of perception concerning organisational support, will have higher positive attitudes towards their job and, consequently, their turnover intentions decrease. In accordance with the results of these

\section{Figure 1 Theoretical framework and hypotheses}

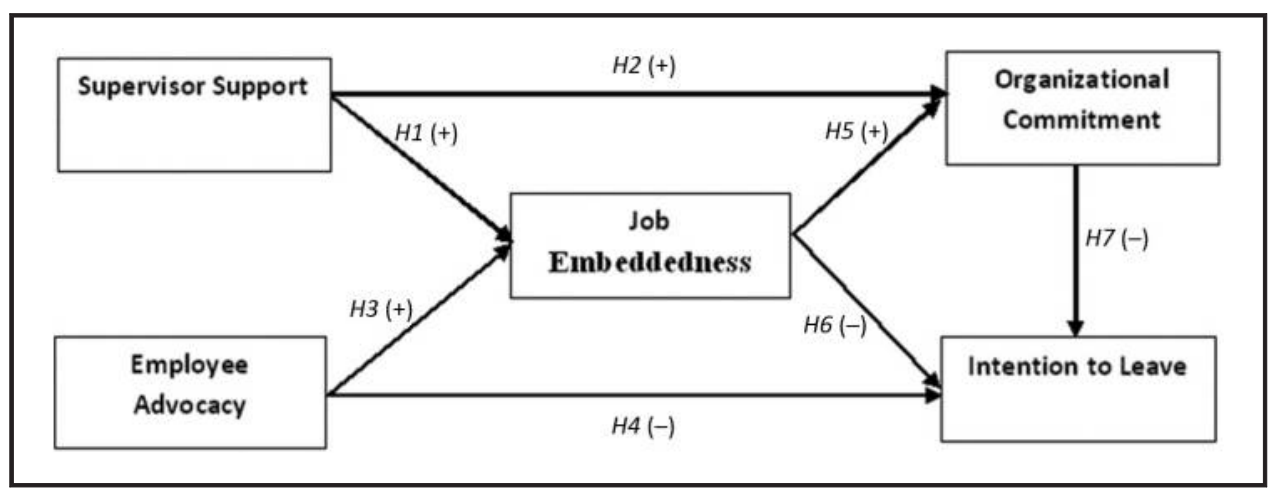


studies, it is expected in this research that employees' perceptions regarding organisational support in the airline industry can positively affect both job embeddedness and organisational commitment:

H1. Perceived organisational support has a positive effect on job embeddedness.

H2. Perceived organisational support has a positive effect on organisational commitment.

\section{Employees' advocacy, job embeddedness and turnover intentions}

Furthermore, it is possible to explain the association between job embeddedness and intentions to leave and employees' advocacy based on SET and RNT. When organisations invest in their employees' happiness, employees will generally have the tendency to show positive behaviours towards their organisations. In this context, it is expect that the high level of employees' advocacy is likely to reduce the negative considerations and turnover intentions of employees. In the literature, there are few studies addressing the concepts of employees' advocacy and job embeddedness. The empirical studies found out a significant association between: employees' advocacy and their turnover intention (Akgündüz and Sanli, 2017; Yeh, 2014; Pang et al., 2015); job embeddedness and intentions to leave (Akgündüz and Cin, 2015; Peltokorpi et al., 2017); and employees' advocacy and job embeddedness (Akgündüz and Cin, 2015). In addition, the turnover intention of employees has been found to be negatively influenced by the employees' advocacy (Yeh, 2014; Singh and Sharma, 2016) and job embeddedness (Crossley et al., 2007; Robinson et al., 2014). Accordingly, the higher the employees' advocacy, the higher is job embeddedness and the lower is turnover intention of employees. Likewise, in the present research, it is expected that the employees' advocacy perceptions in the airline industry influence positively the job embeddedness. Therefore, the following hypotheses have been investigated and developed:

H3. Employee advocacy has a positive effect on job embeddedness.

H4. Employee advocacy has a negative effect on turnover intention.

\section{Job embeddedness, organisational commitment and intention to leave}

The current research focuses on investigating the effect of job embeddedness on employees' turnover in the airline industry setting. Numerous studies have provided a theoretical and empirical evidence for job turnover and showed that employees' intentions to leave is a significantly affected by embeddedness (Holtom et al., 2006; Allen, 2006; Crossley et al., 2007; Robinson et al., 2014; Karatepe, 2016). Many different studies also addressed job satisfaction and organisational commitment as investigators. For instance, Chen (2006) and Tanova and Holtom (2008) argued that there is an integration between job embeddedness and the traditional attitudinal-based models of turnover. In a supportive context, they mentioned that job embeddedness interprets a large proportion of the variance higher than and beyond the indicators of job satisfaction and organisational commitment. They also pointed out that decisions concerning turnover are related not only to job demographics, attitudes and labour market opportunities, but also to the degree of actual and perceived interdependence to one's job and society.

Felps et al. (2009) compiled a hospitality sample with some other industries and confirmed the important role played by job embeddedness of employees. In their study conducted on front line employees at hotel setting, Karatepe and Ngeche (2012) revealed that job embeddedness is a mediator between employees' engagement and job performance. In addition, previous studies conducted in other settings (Lee et al., 2004; Halbesleben and Wheeler, 2008; Karatepe, 2016; Ferreira et al., 2017) indicated that job embeddedness of employees mediates the association between their turnover intentions and job performance. 
With respect to the sole etusy on hospitality, it indicates that there is a mediation role of job embeddedness in the relation between empowerment and service recovery performance (Karatepe and Karadas, 2012; Ferreira et al., 2017; Lu et al., 2016).

Furthermore, some studies have investigated the different influences emerged as a result of some organisational and community sub-factors (Lee et al., 2004; Allen, 2006; Wheeler et al., 2010; Bibi and Jadoon, 2018). These studies dealt with the first-order sub-variables of job embeddedness as equally weighted factors and compiled them to shape composites. Results adopting this approach are mixed in different ways. For example, the study conducted by Allen (2006) have asserted that organisational embeddedness is the strongest predictor of turnover intentions, whereas Lee et al. (2004) indicated that community embeddedness is a more stronger predictor. Nevertheless, Smith et al. (2011) mentioned that it is not obvious what conditions specify the relative significance of one subvariable over another.

Moreover, previous research (Allen, 2006; Holtom et al., 2006; Crossley et al., 2007; Robinson et al., 2014; Bibi and Jadoon, 2018; Coetzer et al., 2017) argued that higher levels of employees' feelings regarding job embeddedness are positively associated with higher levels of organisational commitment, while the association between job embeddedness and intentions to leave is found to be negative. Job embeddedness framework provided by Mitchell et al. (2001) and Robinson et al. (2014) suggested that when an employee's own values, career goals and future plans are consistent with the job demands, they experience an alignment with the larger corporate culture and feel suited with the surrounding environment and community. Thus, employees with job embeddedness are more likely to display a higher degree of commitment towards their organisation, but less likely to have turnover or leaving intentions.

Job embeddedness theory implicitly presents guidance to develop the mediating hypothesised relationships. Organisational systems develop job embeddedness that, in turn, leads to elevated levels of employee retention (Wheeler et al., 2010). Employees are job embedded when they find that they receive support from their supervisors in dealing with work-related problems and obtain support in the family domain to manage their roles effectively. They feel attached to the organisation because they have quality relationships with other individuals in the organisation, fit well with various aspects of the job and organisational culture and know what they will lose as a result of voluntary turnover.

Furthermore, DeConinck and Johnson (2009) emphasised that employees with a low level of organisational commitment are more likely to show negative work outcomes such as job-search behaviour, turnover intention and actual turnover. Turnover intention can be referred to of employees' awareness regarding the possibility of leaving organisation in the near future (Mowday et al., 1982; Ampofo et al., 2017; Li et al., 2017), and it represents the strongest predictor of actual turnover behaviour (Joo and Park, 2010). The present research confirms that employees' turnover intentions negatively related to organisational commitment (Joo and Park, 2010; Lee and Bruvold, 2003; Fazio et al., 2017; Lim et al., 2017). In the same context, Kang et al. (2015) examined a model of employees' turnover intention applying on a sample of employees at hotels and found that the turnover intentions of those employees were negatively associated with the level of organisational commitment; they also found that training and development were significant elements to those employees. Moreover, other studies (Hei and Rahim, 2011; Walsh and Taylor, 2007; Ampofo et al., 2017) asserted the importance of the relationship between employees' organisational commitment and their turnover intentions. Hence, it is crucial to concentrate on expanding the relation between organisational commitment and employees' turnover intention in the airline companies; this takes place, respectively, to the high degree of turnover in these companies. Consequently, the following hypotheses can be stated: 
H5. Job embeddedness has a positive influence on job organisational commitment.

H6. Job embeddedness has a negative influence on employees' intention to leave.

H7. Organisational commitment has a negative influence on employees' intention to leave.

\section{Methodology \\ Sample and data collection}

To test the research hypotheses, we used a research approach based on a field survey to collect data from frontline employees working at various airline companies through a questionnaire. In the following sections, we discuss the measures used for this study and data collection process. The setting for the study was 119 commercial airline companies in Egypt. The respondent sample was drawn from frontline employees who worked in the airline companies and had direct interactions with customers. On the basis of the data obtained from the Ministry of Culture \& Tourism of Egypt, there are 119 commercial airline companies in Egypt. The participants were accepted as an infinite population, and the minimum sample size was calculated to be 384 as suggested by Hair et al. (2013).

All questions were translated and back translated by bilingual authors from Arabic to English to avoid language related errors in the analysis. A pilot sample of 40 employees who worked in the airline companies and had direct interactions with customers (personally interviewed) was used to ensure that the wording of the questionnaire was clear and to evaluate the quality of content and reliability of measures. Consequently, a few minor alterations were made to improve our instrument.

To avoid over representation of any single company, an equal number of questionnaires (i.e. ten) was distributed to each airline company. However, the employees' questionnaires were distributed to a sample of 1,190 by the authors using the face-to-face method in April 2017. The survey was anonymous and restricted to frontline employees aged 18 years and above, and was approved by the Human Research Ethics Advisory Panel. A total of 1,190 questionnaires were distributed to employees who had served in their positions for more than 1 year. Managers of each company informed their frontline employees about the survey and encouraged them to participate. All employees received an envelope with a cover letter and a questionnaire. To encourage honesty, employees were given a written guarantee that responses would be confidential. Participants completed the questionnaire during working hours and returned it in a sealed prepaid envelope to the researchers. The survey questionnaire was distributed to 1,190 employees.

Participants were assured of confidentiality and allowed to respond to the survey anonymously during working hours; the total number of received responses 894 responses. In all, the researcher collected 894 employees' questionnaires from the respective HR departments of the participating airline companies. Owing to missing data in some of the questionnaires, 24 employee's questionnaires were eliminated. In all, 870 complete questionnaires were received from employees, which resulted in response rates of 73 per cent. Consequently, the total number of valid responses for further analysis amounted to 870 responses (894-24). Overall, it can be seen from Table I, the employees involved in the sample were mostly 18 to 29 years old (33 per cent), followed by the 40-49 years old (32 per cent). As for their gender, a significantly higher proportion of males were recorded (approx. 53 per cent). This is very culturally in the Middle-Eastern where a male population usually dominates the work place. Ultimately, a great number of airline companies' managers hold at least a Bachelor degree (36). Service employees represented 76 per cent of the total, about one-fourth ( 21 per cent) had worked in their current positions under 2 years and 33 per cent had worked for 2-5 years. 


\begin{tabular}{|c|c|c|c|}
\hline Variable & Category & $N$ & $\%$ of response \\
\hline \multirow[t]{5}{*}{ Age } & $18-29$ & 290 & 33 \\
\hline & 30-39 & 112 & 14 \\
\hline & $40-49$ & 288 & 32 \\
\hline & $50-59$ & 180 & 21 \\
\hline & Over 60 & - & - \\
\hline \multirow[t]{2}{*}{ Gender } & Male & 459 & 53 \\
\hline & Female & 411 & 47 \\
\hline \multirow[t]{4}{*}{ Education } & Bachelor degree & 311 & 36 \\
\hline & Diploma & 129 & 15 \\
\hline & Master or doctorate & 278 & 32 \\
\hline & other & 152 & 16 \\
\hline \multirow[t]{2}{*}{ Position } & Manager & 210 & 24 \\
\hline & Service employees & 660 & 76 \\
\hline \multirow[t]{5}{*}{ Organisational tenure } & Under 2 years & 178 & 21 \\
\hline & 2-under 5 years & 286 & 33 \\
\hline & 5-under 7 years & 210 & 24 \\
\hline & 7 -under 10 years & 119 & 14 \\
\hline & Above 10 years & 77 & 8 \\
\hline
\end{tabular}

\section{Measures}

This research includes five constructs: supervisor support, employees' advocacy, job embeddedness, organisational commitment and intention to leave have been measured during the present study. A five-point Likert scale has been used (from 1 to 5), where 1 reflects the highest disagreement and 5 reflects the highest agreement. A set of items were selected to measure the concept, about which generalisations were made, and it was adapted in respect to related literature to ensure the content validity of the research measurements. Perceived supervisory support was measured through five items adapted from Greenhaus et al. (1990). Many studies have used this scale and ensured its reliability, where alpha correlation coefficients exceed 0.90 in all of these studies (Çakmak-Otluoğlu, 2012; Wickramasinghe and Jayaweera, 2010). The respondents were asked to express their views in terms of the degree of agreement with each item concerning perceived support from their supervisors. Employee advocacy was measured using four items adapted from Yeh (2014). Job embeddedness was also measured based on the job embeddedness global measure proposed by Crossley et al. (2007). For affective organisational commitment, it has been measured through seven items adapted based on the scales developed by Meyer and Allen (1997) and Crossley et al. (2007).

Finally, four items were used to measure the "intentions to leave" construct, and these items have been adapted deepening on Crossley et al.'s (2007) scale. They have designed this scale to avoid content overlap in constructs including job attitudes and job search, accordingly it has been also adopted in a previous study dealt with job embeddedness (Crossley et al., 2007) like it has been used with the items of job embeddedness in the current research.

\section{Data analysis and results}

To establish the nomological validity of the research model, we analysed the survey data using partial least squares (PLS) with a two-step analytic approach. Firstly, the measurement model was evaluated to assess the validity and reliability of the measures. Secondly, the structural model was evaluated to assess the strength of the hypothesised links among the variables. The psychometric properties of all scales were assessed within the context of the structural model through an assessment of discriminant validity and 
reliability. Ruiz et al. (2010) mentioned that the PLS has a set of advantages including the following:

- the ability to deal with the very complicated models;

- producing loadings, coefficients of standardised regression and $R^{2}$ for all endogenous constructs; and

- providing relaxed assumptions concerning the distribution of the research data.

\section{Measurement model}

On the basis of Duarte and Raposo's (2010) study, the present research checked the individual item reliability, internal consistency and discriminate validity so that the measurement model for the research constructs can be evaluated. The results have revealed that there were 26 items had loading rates above 0.70 reflecting the acceptable levels of reliability, while only one item was found to have a loading rate of 0.402 . Concerning examining the cross-loadings, the loadings of all items were found higher for their related construct than for other research constructs (Table II). Tests of normality, namely, skewness, kurtosis and Mahalanobis distance statistics (Bagozzi and Yi, 1988), have been conducted (Table Al).

\section{Table II Measurement statistics of construct scales}

\begin{tabular}{|c|c|c|c|c|c|c|c|}
\hline Construct/Indicators & Indicator loadings & $C R$ & Cronbach's $\alpha$ & VIF & AVE & MSV & ASV \\
\hline Intentions to leave & & 0.94 & 0.91 & 2.18 & 0.72 & 0.321 & 0.210 \\
\hline INT1 & 0.95 & & & & & & \\
\hline INT2 & 0.93 & & & & & & \\
\hline INT3 & 0.86 & & & & & & \\
\hline INT4 & 0.92 & & & & & & \\
\hline Organisational commitment & & 0.90 & 0.87 & 1.92 & 0.54 & 0.234 & 0.194 \\
\hline COM1 & 0.94 & & & & & & \\
\hline COM2 & 0.89 & & & & & & \\
\hline COM3 & 0.94 & & & & & & \\
\hline COM4 & 0.97 & & & & & & \\
\hline COM5 & 0.88 & & & & & & \\
\hline Job embeddedness & & 0.93 & 0.88 & 1.78 & 0.54 & 0.304 & 0.203 \\
\hline EMP1 & 0.95 & & & & & & \\
\hline EMP2 & 0.94 & & & & & & \\
\hline EMP3 & 0.88 & & & & & & \\
\hline EMP4 & 0.89 & & & & & & \\
\hline EMP5 & 0.94 & & & & & & \\
\hline EMP6 & 0.92 & & & & & & \\
\hline EMP7 & 0.87 & & & & & & \\
\hline Employee advocacy & & 0.95 & 0.92 & 1.94 & 0.52 & 0.434 & 0.039 \\
\hline ADV1 & 0.96 & & & & & & \\
\hline ADV2 & 0.94 & & & & & & \\
\hline ADV3 & 0.95 & & & & & & \\
\hline ADV4 & 0.92 & & & & & & \\
\hline Supervisor support & & 0.92 & 0.90 & 2.01 & 0.67 & 0.327 & 0.214 \\
\hline SUP1 & 0.94 & & & & & & \\
\hline SUP2 & 0.91 & & & & & & \\
\hline SUP3 & 0.93 & & & & & & \\
\hline SUP4 & 0.89 & & & & & & \\
\hline SUP5 & 0.94 & & & & & & \\
\hline
\end{tabular}

Notes: INT = Intentions to leave; COM = Organisational commitment; EMP = Job embeddedness; ADV = Employees advocacy; SUP = Supervisor support; VIF = Variance inflation; MSV = Maximum shared squared variance; $A S V=$ Average shared squared variance 
The measurement model's internal consistency is investigated through the composite reliability index and average variance extracted (AVE; Fornell and Larcker, 1981). It has been found that the composite reliabilities for all of the research constructs exceeding the acceptable level of 0.70 (Nunnally and Bernstein, 1994; Table II), and the average variance extracted for each construct measure were above the minimum acceptable level of 0.50 (Bagozzi and Yi, 1988; Table II). Consequently, it concluded that the internal consistency of the research measurement model is valid. The discriminant validity of the measurement model was examined by comparing the square root of the average variance extracted with the correlations among the research constructs (Fornell and Larcker, 1981). The correlation between each construct and its own measure found to be stronger than that exists between a construct and any other construct, which ensures the discriminate validity for all of the research constructs. Furthermore, the AVE square root for all variables was greater than its correlations with any other variable in all cases, which supports the discriminant validity of the study constructs (Klarner et al., 2013; see Table III). Hair et al. (2017) suggested that the MSV and the ASV value should be less than the AVE for the discriminant validity. Table II shows that the ASV and the MSV value are less than 25 the AVE value for each construct, which supports the discriminant validity of the measurement model. In addition, Harman's one-factor test was used to check common method bias. The five items of supervisors' support, four items of employee advocacy, seven items measuring job embeddedness, five items of organisational commitment and four items of intention to leave were entered in a principal component factor analysis. The results show that the first factors in the model explained 39.705 per cent of the variance. Thus, common method bias was not an issue.

\section{Structural model}

After examining the measurement validity, we used Smart PLS to test the structural model. The significance of the paths was determined using the T-statistic calculated with the bootstrapping technique. The results reveal that the SEM fits well the research data: for Job embeddedness, $R^{2}=0.62$, organisational commitment, $R^{2}=0.47$ and for intention to leave, $R^{2}=0.66$. Indicators of the global fit is found to be acceptable, in which average path coefficient $($ APC $)=0.189(p$-value $<0.001)$, AARS $=0.720(p$-value $<0.001)$, average $R$ squared $($ ARS $)=0.752(p$-value $<0.001)$, average variance inflation factor $(A V I F)=2.569$ and goodness of fit $(G O F)=0.721$. The results indicate that all hypotheses significantly supported except the hypothesis number four (Figure 2)

H1 proposed that organisational support has a strong positive relationship with job embeddedness. As expected, the effects of supervisor's support on job embeddedness has a significant impact; the coefficient was $\beta=0.56, p<0.001$. Therefore, the first hypothesis (H1) is undeniable affirmed and, thus, supported. This means that the more organisational support is the more likely employees will show higher levels of job embeddedness.

\section{Table III Discriminant validity of the correlations between constructs}

\begin{tabular}{lccccc} 
Construct & SUP & \multicolumn{4}{c}{ Correlations and square roots of AVE } \\
& ADV & EMP & COM & INT \\
\hline SUP & $(0.827)$ & & & & \\
ADV & 0.649 & $(0.807)$ & & & \\
EMP & 0.541 & 0.531 & $(0.847)$ & & \\
COM & 0.509 & 0.608 & 0.579 & $(0.847)$ & \\
INT & 0.631 & 0.573 & 0.404 & 0.551 & $(0.893)$
\end{tabular}

Notes: INT = Intentions to leave; COM = Organisational commitment; EMP = Job embeddedness; ADV = Employees advocacy; SUP = Supervisor support 


\section{Figure 2 PLS analysis results}

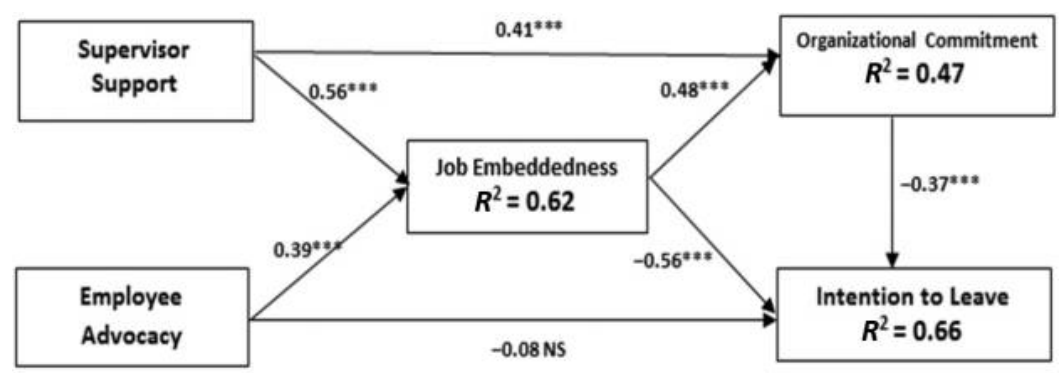

Note: the asterisk represents the significant level of coefficient. * $0.05 ; * * 0.01$; *** $0.001 ; \mathrm{NS}=$ Not significant

H2 proposed that organisational support has a strong positive effect on organisational commitment. As expected, the effects of supervisor's support on organisational commitment has a significant impact; the coefficient was $\beta=0.41, p<0.001$. Therefore, the second hypothesis $(H 2)$ is supported. This means that the more organisational support is the more likely employees will show higher levels of commitment.

H3 proposed that employees' advocacy has a strong positive effect on job embeddedness. As expected, the effects of employee advocacy on job embeddedness has a significant impact; the coefficient was $(\beta=0.39, p<0.001)$. Therefore, the third hypothesis $(H 3)$ is supported. This means that the more employee advocacy is the more likely employees will show higher levels of job embeddedness.

H4 proposed that employee advocacy has a negative effect on turnover intention. Despite the authors' expectation, employees' advocacy has no significant influence on their intentions to leave. Consequently, the fourth hypothesis $(\mathrm{H} 4)$ was abandoned or rejected. It means that employee advocacy directly does not affect the turnover intention. Job embeddedness acts as a link between employee advocacy and turnover intention.

H5 proposed that job embeddedness has a strong positive effect on organisational commitment. As expected, the effects of job embeddedness on organisational commitment has a significant impact; the coefficient was $\beta=0.48, p<0.001$. Therefore, the fifth hypothesis (H5) is supported. This means that the more job embeddedness is the more likely employees will show higher levels of commitment.

As expected, the effects of job embeddedness on intention to leave has a significant impact; the coefficient was $\beta=-0.56, p<0.001$. Therefore, the sixth hypothesis $(H 6)$ is supported. This means that the more job embeddedness is the more likely employees will show lower levels of intention to leave.

$H 7$ proposed that organisational commitment has a negative effect on employees' intention to leave. As expected, the effects of organisational commitment on employees' intention to leave has a significant impact; the coefficient was $\beta=-0.37, p<0.001$. Therefore, the seventh hypothesis (H7) is supported. This means that the more organisational commitment is the more likely employees will show lower levels of commitment.

To investigate the mediating influences of the variables on intention to leave on the basis of job embeddedness and organisational commitment, a separate analysis was performed depending on Baron and Kenny's (1986) procedure. The findings showed that the effects of supervisor support and employees' advocacy on employees' intention to leave partially mediated by job embeddedness and organisational commitment. 
Moreover, the effect size $f^{2}$ suggested by Cohen (1992), which is "the degree to which the phenomenon is present in the population", has been adopted to investigate the substantive influence of the research model. Cohen (1992) mentioned that operational definitions of large, medium and small effect sizes were 0.35, 0.15 and 0.02, respectively. Hence, the research model conclude that both job embeddedness and intentions to leave have a high effect size, where $f^{2}=0.65$ and $f^{2}=0.49$, respectively, whereas organisational commitment has a medium effect size $f^{2}=0.24$.

The predictive validity of the structural model tasted in the present research based on the Stone-Geisser $Q^{2}$. The cross-validated construct redundancy $Q^{2}$ can be used as a prerequisite for investigating the model predictive validity (Roldán and Sánchez-Franco, 2012). When $Q^{2}$ is above 0 , this emphasises the predictive validity of the research model. In the present research, the $Q^{2}$ for job embeddedness, organisational commitment and intentions to leave were $0.61,0.53$ and 0.47 , respectively, which is considered positive and matched the previously mentioned condition.

\section{Discussion and conclusions}

The importance of employees' job embeddedness perception in the airline companies has not been provided indispensable attention. To identify the role of frontline employees' job embeddedness perception, this research has proposed and investigated a model that examines the determinants and outcomes of employees' job embeddedness in the airline companies. Supervisor support and employee advocacy have been proposed as two factors for building job embeddedness. Nevertheless, both organisational commitment and intention to leave were addressed as consequences to job embeddedness.

On testing the first hypothesis, it was found that supervisor support had a strong positive relationship with job embeddedness, which signified that high degree of employees' perception regarding the supervision's support leads to a higher degree of employees' job embeddedness, and enhances their positive attitudes towards jobs. This result is supported by previous studies conducted by various researchers (Akgündüz and Cin, 2015; Takawira et al., 2014; Akgündüz and Sanli, 2017).

On testing second hypothesis, it was found that perception of frontline employees concerning supervisory support has a positive influence on affective organisational commitment. This is found to be consistent with some previous studies (Pattie et al., 2006; Dawley et al., 2010; Kang et al., 2015). It can be stated that supervisors often represent all that is good or not good concerning an organisation. This is in terms of providing the needed support for their employees.

The results indicate that perceived organisational support enhances the job embeddedness of the employees and reduces their turnover intentions. This research provides an empirical support to Chiang and Hsieh's (2012) and Tsai et al.'s (2015) studies that suggested that employees who perceive that they are valued and their rights are protected showing better attitudes towards their organisations.

It can be predicted that employee advocacy would positively affect job embeddedness. This hypothesis has been also supported, in which the findings confirmed that employees who perceive that their employers appreciate and consider their interests have positive attitudes towards their organisation. Regarding the research hypothesis, which implies that employee advocacy would have a significant negative influence on turnover intention, the findings did not provide support for that. This result shows that employees' turnover intentions are not influenced by attitudes and attempts of managers to protect the interests of their employees. This relationship has also been proved by previous studies conducted by various researchers (Takawira et al., 2014; Akgündüz and Sanli, 2017). 
The job embeddedness of employees plays a significant role in increasing organisational commitment and decreasing turnover intention (Afsar and Badir, 2016; Burton, 2014; Tanova and Holtom, 2008). The results demonstrate that perceived organisational support appears to be a potential solution. This is consistent with other empirical studies, which indicate that perception of employees concerning organisational support increases job embeddedness as well as with RNT. This result shows that the employees' job embeddedness significantly increases when they perceive it. Accordingly, their needs are supported and their contributions are appreciated and valued by the organisation.

On testing Hypotheses 5, 6 and 7, it was found that job embeddedness had a significant influence on organisational commitment and intention to leave, which signified the better job embeddedness, the higher the commitment of the employees towards their organisations. Furthermore, the currents study reveals that organisational commitment had a negative influence on employees' intention to leave. This is found to be consistent with some previous studies (Kang et al., 2015; Akgündüz and Sanli, 2017; Hei and Rahim, 2011; Walsh and Taylor, 2007).

In addition, this research found out that job embeddedness increases when employees perceive that there are employee advocacy practices. This result indicates that if employees see that their interests are protected and ensured, information is shared freely, and the management tries to increase their satisfaction, then consequently, the job embeddedness of those employees will increase. Moreover, it is found out that there is a negative correlation between job embeddedness and turnover intention in this research. This finding supports the work of Crossley et al. (2007) and Karatepe and Shahriari (2014); they had argued that employees' termination of employment may cause financial and nonmaterial costs to them and may damage their fit relationships with the organisation and society.

\section{Practical implications}

In respect to the results brought up by the present research, there are some significant implications for business practice that could be beneficial from a managerial perspective. Firstly, the high levels of supervisory support behaviour displayed by managers help employees to feel that their efforts and hopes are understood and appreciated. Exceptional supervisors who give tasks matching with employees' skills, confirms some aspects including:

- displaying actions that are compatible with words;

- offering employees the chance to learn how to enhance their performance; and

- showing respect towards employees.

Airline companies that deal with a subculture or counterproductive employees, which lacks engaged employees, should provide crucial resources and training for their supervisors. In respose, supervisors can provide support to their employees who are dealing with difficult work conditions. In addition, attention should be provided to supervisors who have recently been promoted and who would confront challenge of providing their employees with required support leading to a higher organisational commitment. Employees receiving continuous support from their supervisors would be more attached to the job as frontline service jobs are stressful requiring long work hours. Therefore, management of the airlines companies should arrange training programs that focus mainly on the critical role of support emerging from supervisors. During such planned training programs, managers may use case studies to precisely define the importance of work support. They may receive feedback from frontline employees about how to maximise support arising from supervisors and co-workers. In such training programmes, supervisors should also practise on how to deal with employees' work and family problems and to offering potential solutions. Having 
an appropriate work environment facilitating social support would raise the team spirit among supervisory and non-supervisory employees.

Secondly, airline employees interact with customers and deal with a number of their complaints and requests. For this reason, employee candidates whose skills and attitudes are compatible with the company's plans, purposes and values should be included in the recruitment process of the organisation and placed in departments in which employees work face-to-face with customers. When the job embeddedness of the employees who intrinsically meet the company's purposes and values is higher, the turnover intention of such employees decreases. Airline companies can enhance job embeddedness of their employees by creating opportunities through which employees can improve themselves, by allowing employees to use their skills efficiently, by helping their career planning and by applying teamwork in the organisation. For instance, inadequate training in the airline industry is one of the problems impeding emotion work and engendering safety problems. Therefore, creating chances for continuous training and re-training programmes through video cases is a very indispensable affair. Throughout such training programmes, employees should also learn the approaches leading them to recognise and to practice empowerment. Accordingly, they should learn how to deal with passengers' requests and problems successfully and to cope with passengers who show dysfunctional behaviours.

Thirdly, to let employees realise how much support they receive airline companies' managers should provide comfortable working conditions for their employees, to act in a rightful manner, make sure that employees are involved in decision-making processes and that they are directly related to workers and finally take complaints and suggestions of the employees into consideration. In this manner, airline companies' managers can enhance the job embeddedness of employees; consequently, the turnover intention can be reduced. Establishing team spirit and solidarity among employees and developing the importance of teamwork in training and retraining programs that is known as pays dividends. Such training programmes would be a tool to stimulate teamwork and to motivate employees to generate new ideas for achieving forms of improvement in the service delivery and passenger complaint-handling processes. Employees who are capable of responding to passengers' requests have to deal with a number of problems that are effective and thus lead to team success. Such efforts should also be recognised and rewarded.

Finally, the results of the present study provide an opportunity for airlines organisations to increase the job embeddedness of their employees by increasing perceived costs of leaving. Airlines organisations need to embed their employees more fully, while they might also facilitate this outcome through changes to their selection and retention processes. Recruitment, selection and socialisation to an organisation was considered vital, leading to accomplishment of an organisation for a long term. Moreover, selecting employees who are supportive of organisational goals and values is crucial. In addition, the unique working conditions of this industry, including seasonality, irregular working hours, reproductive and often unskilled work need to be considered in building job embeddedness. The evidence is that the intrinsic rewards offered, such as autonomy and creativity are more likely to create organisational commitment for airlines employees. Specific tactics managers, who can be employed in this regard, might be aware enough to include input into measurement indicators of work team performance, menu design for food and beverage staff and empowering front office staff in exceeding guest needs. These strategies are likely to deflect employees' attention from the industry's immutable structural characteristics that their organisations are subject to target, and cannot fully control. Finally, in addition, job embeddedness functions as a full mediator of the effects of supervisor support and employees' advocacy on commitment and intention to leave. This is congruent with the precepts of job embeddedness theory that job embeddedness is a key variable linking onand off-the-job variables to employee outcomes (Karatepe, 2013). 


\section{Theoretical implications}

The current study has several theoretical implications, which can add to the body of the knowledge in various ways: Firstly, in the airline context, job embeddedness considers a major factor that can support employees' behavioural intentions. So identifying factors affecting employees' job embeddedness will give us a clear picture on how to increase employees' commitment and, thus, their intentions to leave. Secondly, the current study investigated the mediating role of job embeddedness in the relationship between supervisors support and their intentions to leave, which have not investigated in the airline context. Thirdly, previous studies call for investigating the role of job embeddedness in countries other than the developed countries, the current study investigates the drivers and outcomes of job embeddedness in different developing cultural contexts (Egypt). Our results indicate that supervisor's support and employees' advocacy are important drivers of job embeddedness in the developing countries. Finally, the findings of this study clarify previous inconsistent findings on the importance of supervisors' support and employees' advocacy. Supervisors' support and employees' advocacy play a crucial role in developing job embeddedness in collectivistic and high context culture (e.g. Egypt).

\section{Limitations and areas for future research}

In accordance with other researches, the present research could not overcome all challenges in this domain; however, it can give insight for further coming. Firstly, this research examined the organisational support and employee advocacy only from the perspective of employees. Future research could aim to identify the behaviours of airline companies' managers towards their employees so that both employees' perceptions and managers' behaviours are matched. The data collection period could also be extended across a longer period as organisational support and employee advocacy are not daily activities. Secondly, the research variables have been measured at a specific period. Therefore, future research is recommended to handle longitudinal analysis to examine the validity of suggested model developed in the present research.

This research focuses only on studying the nature of relationships among certain variables including supervisory support, employee advocacy, job embeddedness, organisational commitment and turnover intention. Future research can add other variables such as trust (both organisational and supervisory trust) or leader-member exchange to develop and to enhance model suggested in this study. Culture has to be taken into account as a suitable mediating variable (individualism/collectivism) because they have different expectations. In addition, interviews with supervisors are supportive to identify reasons concerning their failure to provide necessary support to their subordinates. It is argued that supporting the level of organisational commitment and decreasing the level of turnover intensions are a substantial priority for the airline industry, the best practices concerning supervisors' support and investigating the reasons leading to the question why the supervision's support might be insufficient, has to be a focus for future studies. Finally, studying the differences between male and female employees would make a worthwhile contribution to the body of knowledge.

\section{References}

Afsar, B. and Badir, Y.F. (2016), "Person-organization fit, perceived organizational support, and organizational citizenship behavior: the role of job embeddedness", Journal of Human Resources in Hospitality \& Tourism, Vol. 15 No. 3, pp. 252-278.

Afsar, B., Shahjehan, A. and Shah, S.I. (2018), "Frontline employees' high-performance work practices, trust in supervisor, job-embeddedness and turnover intentions in hospitality industry", International Journal of Contemporary Hospitality Management, Vol. 30 No. 3, pp. 1436-1452.

Akgündüz, Y. and Cin, F.M. (2015), "Job embeddedness as a moderator of the effect of manager trust and distributive justice on turnover intentions", Anatolia, Vol. 26 No. 4, pp. 549-562. 
Akgündüz, Y. and Sanli, S.C. (2017), "The effect of employee advocacy and perceived organizational support on job embeddedness and turnover intention in hotels", Journal of Hospitality and Tourism Management, Vol. 31, pp. 118-125.

Allen, D.G. (2006), "Do organizational socialization tactics influence newcomer embeddedness and turnover?", Journal of Management, Vol. 32 No. 2, pp. 237-256.

Alonso, A.D. and O'Neill, M.A. (2011), "What defines the 'ideal' hospitality employee? A college town case", International Journal of Hospitality \& Tourism Administration, Vol. 12 No. 1, pp. 73-93, doi: 10.1080/ 15256480.2011 .540986$.

Ampofo, E.T., Coetzer, A. and Poisat, P. (2017), "Relationships between job embeddedness and employees' life satisfaction", Emplovee Relations, Vol. 39 No. 7, pp. 951-966.

Anvari, R., JianFu, Z. and Chermahini, S.H. (2013), "Effective strategy for solving voluntary turnover problem among employees", In International Conference on Innovation, Management and Technology Research, Malaysia.

Azanza, G., Moriano, J.A., Molero, F. and Mangin, J.P. (2015), "The effects of authentic leadership on turnover intention", Leadership \& Organization Development Journal, Vol. 36 No. 8, pp. 955-971.

Bagozzi, R. and Yi, Y. (1988), "On the evaluation of structural equation models", Journal of the Academy of Marketing Science, Vol. 16 No. 1, pp. 74-94.

Baron, R.M. and Kenny, D.A. (1986), "The moderator-mediator variable distinction in social psychological research: conceptual, strategic, and statistical considerations", Journal of Personality and Social Psvchology, Vol. 51 No. 6, pp. 1173-1182.

Bentley, T.A., Teo, S.T.T., McLeod, L., Tan, F., Bosua, R. and Gloet, M. (2016), "The role of organisational support in teleworker wellbeing: a socio-technical systems approach", Applied Ergonomics, Vol. 52, pp. 207-215

Bibi, A. and Jadoon, B. (2018), "The mediating effect of exploitative and explorative learning on the relationship between job embeddedness and innovative work behavior", innovation, Vol. 6 No. 1, pp. 1-8.

Biron, M. and Boon, C. (2013), "Performance and turnover intentions: a social exchange perspective", Journal of Managerial Psychology, Vol. 28 No. 5, pp. 511-531.

Blau, P. (1964), Power and Exchange in Social Life, John Wiley \& Sons, New York, NY.

Bos-Nehles, A.C. and Meijerink, J.G. (2018), "HRM implementation by multiple HRM actors: a social exchange perspective", The International Journal of Human Resource Management, pp. 1-25, available at: https://doi.org/10.1080/09585192.2018.1443958

Burke, R.J. (2003), "Nursing staff attitudes following restructuring: the role of perceived organizational support, restructuring processes and stressors", International Journal of Sociologv and Social Policy, Vol. 23 Nos 8/9, pp. 129-157.

Burke, M.J., Borucki, C.C. and Hurley, A.E. (1992), "Reconceptualizing psychological climate in a retail service environment: a multiple-stakeholder perspective”, Journal of Applied Psychology, Vol. 77 No. 5 , pp. 717-729.

Burton, J.P. (2014), "The role of job embeddedness in the relationship between bullying and aggression", European Journal of Work and Organizational Psvchologv, Vol. 24 No. 4, pp. 518-529, available at: http:// dx.doi.org/10.1080/1359432X.2014.944169

Çakmak-Otluoğlu, K.Ö. (2012), "Protean and boundaryless career attitudes and organizational commitment: the effects of perceived supervisor support", Journal of Vocational Behavior, Vol. 80 No. 3, pp. 638-646.

Chen, C.F. (2006), “Job satisfaction, organizational commitment, and flight attendants' turnover intentions: a note”, Journal of Air Transport Manaqement, Vol. 12 No. 5, pp. 274-276.

Chiang, C.F. and Hsieh, T.S. (2012), "The impacts of perceived organizational support and psychological empowerment on job performance: the mediating effects of organizational citizenship behavior", International Journal of Hospitality Management, Vol. 31 No. 1, pp. 180-190.

Coetzer, A., Inma, C. and Poisat, P. (2017), "The job embeddedness-turnover relationship: effects of organisation size and work group cohesion", Personnel Review, Vol. 46 No. 6, pp. 1070-1088.

Cohen, J. (1992), "Statistical power analysis", Current Directions in Psychological Science, Vol. 1 No. 3, pp. 98-101. 
Cropanzano, R. and Mitchell, M.S. (2005), "Social exchange theory: an interdisciplinary review", Journal of Management, Vol. 31 No. 6, pp. 874-900.

Crossley, C.D., Bennett, R.J., Jex, S.M. and Burnfield, J.L. (2007), "Development of a global measure of job embeddedness and integration into a traditional model of voluntary turnover", Journal of Applied Psychology, Vol. 92 No. 4, pp. 1031-1042.

Dawley, D., Houghton, J.D. and Bucklew, N.S. (2010), "Perceived organizational support and turnover intention: the mediating effects of personal sarcifice and job fit", Journal of Social Psychology, Vol. 150 No. 3, pp. 238-257.

Dawson, M. and Abbott, J. (2011), "Hospitality culture and climate: a proposed model for retaining employees and creating competitive advantage", International Journal of Hospitality and Tourism Administration, Vol. 12 No. 4, pp. 289-304, doi: 10.1080/15256480.2011.614533.

DeConinck, J.B. and Johnson, J.T. (2009), "The effects of perceived supervisor support, perceived organizational support, and organizational justice on turnover among salespeople", Journal of Personal Selling and Sales Management, Vol. 29 No. 4, pp. 333-351.

Duarte, P.A.O. and Raposo, M.L.B. (2010), "A PLS model to study brand preference: an application to the mobile phone market", in Vinzi, V.E., Chin, W.W., Henseler, J. and Wang, H. (Eds), Handbook of Partial Least Squares, Springer, Berlin, Heidelberg, pp. 449-485.

Elbaz, A.M. and Haddoud, M.Y. (2017), "The role of wisdom leadership in increasing job performance: evidence from the Egyptian tourism sector”, Tourism Management, Vol. 63, pp. 66-76.

Elbaz, A.M., Haddoud, M.Y. and Shehawy, Y.M. (2018), "Nepotism, employees' competencies and firm performance in the tourism sector: a dual multivariate and qualitative comparative analysis approach", Tourism Management, Vol. 67, pp. 3-16.

Eisenberger, R., Stinglhamber, F. and Vandenberghe, C. (2002), "Perceived supervisor support: contributions to perceived organizational support and employee retention", Journal of Applied Psychology, Vol. 87 No. 3, pp. 565-573, available at: http://dx.doi.org/10.1037/0021-9010.87.3.565

Eisenberger, R., Armeli, S., Rexwinkel, B., Lynch, P.D. and Rhoades, L. (2001), "Reciprocation of perceived organizational support", Journal of Applied Psychology, Vol. 86 No. 1, pp. $42-51$.

Emerson, R.M. (1976), "Social exchange theory", Annual Review of Sociologv, Vol. 2 No. 1, pp. 335-362.

Fazio, J., Gong, B., Sims, R. and Yurova, Y. (2017), "The role of affective commitment in the relationship between social support and turnover intention”, Manaqement Decision, Vol. 55 No. 3, pp. 512-525.

Felps, W., Mitchell, T.R., Hekman, D.R., Lee, T.W., Holtom, B.C. and Harman, W.S. (2009), "Turnover contagion: how coworkers' job embeddedness and job search behaviors influence quitting", Academv of Management Journal, Vol. 52 No. 3, pp. 545-561.

Ferreira, A.I., Martinez, L.F., Lamelas, J.P. and Rodrigues, R.I. (2017), "Mediation of job embeddedness and satisfaction in the relationship between task characteristics and turnover: a multilevel study in Portuguese hotels", International Journal of Contemporary Hospitality Management, Vol. 29 No. 1, pp. 248-267.

Fornell, C. and Larcker, D.F. (1981), "Evaluating structural equation models with unobservable variables and measurement error", Journal of Marketing Research, Vol. 18 No. 1, pp. 39-50.

Gouldner, A.W. (1960), "The norm of reciprocity: a preliminary statement", American Sociological Review, Vol. 25 No. 2, pp. 161-178.

Greenhaus, J.H., Parasuraman, S. and Wormley, W.M. (1990), "Effects of race on organizational experiences, job performance evaluations, and career outcomes", Academv of Management Journal, Vol. 33 No. 1, pp. 64-86.

Hair, J.F., Hult, G.T.M., Ringle, C. and Sarstedt, M. (2017), A Primer on Partial Least Squares Structural Equation Modeling (PLS-SEM), 2nd ed., Sage, Thousand Oaks, CA.

Hair, J.F., Ringle, C.M., Hult, G.T. and Sarstedt, M. (2013), A Primer on Partial Least Squares Structural Equation Modeling (PLS-SEM), SAGE Publications, Thousand Oaks, CA.

Halbesleben, J.R. and Wheeler, A.R. (2008), "The relative roles of engagement and embeddedness in predicting job performance and intention to leave", Work \& Stress, Vol. 22 No. 3, pp. 242-256.

Haque, A., Fernando, M. and Caputi, P. (2017), "The relationship between responsible leadership and organisational commitment and the mediating effect of employee turnover intentions: an empirical study with Australian employees", Journal of Business Ethics, pp. 1-16. 
Harhara, A.S., Singh, S.K. and Hussain, M. (2015), "Correlates of employee turnover intentions in oil and gas industry in the UAE", International Journal of Organizational Analysis, Vol. 23 No. 3, pp. 493-504.

Harpert, V.L. (2013), “Job satisfaction, perceived availability of job alternatives and turnover intentions: the case of the alumina industry in Suriname", Maastricht School of Management.

Hei, M.A. and Rahim, A.R.A. (2011), "The effect of psychological contract and affective commitment on turnover intentions of hotel managers", International Journal of Business and Social Science, Vol. 2 No. 23, pp. 76-88.

Hemdi, M.A. and Nasurdin, A.M. (2006), "Predicting turnover intentions of hotel employees: the influence of employee development human resource management practices and trust in organization", Gadiah Mada International Journal of Business, Vol. 8 No. 1, pp. 21-42, available at: http://dx.doi.org/10.22146/ gamaijb.5625

Himle, D.P., Jayaratne, S. and Thyness, P.A. (1989), "The buffering effects of four types of supervisory support on work stress", Administration in Social Work, Vol. 13 No. 1, pp. 19-34.

Hinken, T.R. and Tracey, J.B. (2000), "The cost of turnover: putting, a price on the learning curve", The Cornell Hotel and Restaurant Administration Quarterly, Vol. 41 No. 3, pp. 14-21, available at: http://dx.doi. org/10.1016/S0010-8804(00)80013-0

Hofstede, G. and Hofstede, G.J. (2005), Cultures and Organizations - Software of the Mind, 2nd ed., McGraw-Hill, New York, NY.

Holtom, B.C., Mitchell, T.R. and Lee, T.W. (2006), "Increasing human and social Capital by applying job embeddedness theory", Orqanizational Dvnamics, Vol. 35 No. 4, pp. 316-331.

Hom, P.W. and Griffeth, R.W. (1995), Employee Turnover, South/Western, Cincinnati.

Hom, P.W., Tsui, A.S., Wu, J.B., Lee, T.W., Zhang, A.Y., Fu, P.P. and Li, L. (2009), "Explaining employment relationships with social exchange and job embeddedness", Journal of Applied Psvchologv, Vol. 94, pp. 277-297, doi: 10.1037/a0013453.

Ilkhanizadeh, S. and Karatepe, O.M. (2017), "An examination of the consequences of corporate social responsibility in the airline industry: work engagement, career satisfaction, and voice behavior", Journal of Air Transport Management, Vol. 59, pp. 8-17.

Joo, B.-K. and Park, S. (2010), "Career satisfaction, organizational commitment, and turnover intention", Leadership \& Organization Development Journal, Vol. 31 No. 6, pp. 482-500.

Kang, H.J., Gatling, A. and Kim, J. (2015), "The impact of supervisory support on organizational commitment, career satisfaction, and turnover intention for hospitality frontline employees", Journal of Human Resources in Hospitality \& Tourism, Vol. 14 No. 1, pp. 68-89.

Karatepe, O.M. (2011), "Service quality, customer satisfaction and loyalty: the moderating role of gender", Journal of Business Economics and Management, Vol. 12 No. 2, pp. 278-300.

Karatepe, O.M. (2013), "High-performance work practices, work social support and their effects on job embeddedness and turnover intentions", International Journal of Contemporary Hospitality Management, Vol. 25 No. 6, pp. 903-921.

Karatepe, O.M. (2016), "Does job embeddedness mediate the effects of coworker and family support on creative performance? An empirical study in the hotel industry", Journal of Human Resources in Hospitality \& Tourism, Vol. 15 No. 2, pp. 119-132.

Karatepe, O.M. and Karadas, G. (2012), "The effect of management commitment to service quality on job embeddedness and performance outcomes", Journal of Business Economics and Management, Vol. 13 No. 4, pp. 614-636.

Karatepe, O.M. and Ngeche, R.N. (2012), "Does job embeddedness mediate the effect of work engagement on job outcomes? A study of hotel employees in Cameroon", Journal of Hospitality Marketing \& Management, Vol. 21 No. 4, pp. 440-461.

Karatepe, O.M. and Shahriari, S. (2014), "Job embeddedness as a moderator of the impact of organisational justice on turnover intentions: a study in Iran", International Journal of Tourism Research, Vol. 16 No. 1, pp. 22-32.

Khan, S.L. (2015), "Transformational leadership and turnover intention: the mediating effects of trust and performance", Doctoral dissertation, Bangkok University. 
Klarner, P., Sarstedt, M., Hoeck, M. and Ringle, C.M. (2013), "Disentangling the effects of team competences, team adaptability, and client communication on the performance of management consulting teams", Long Range Planning, Vol. 46 No. 3, pp. 258-286.

Kottke, J.L. and Shafranski, C.E. (1988), "Measuring perceived supervisory and organizational support", Educational and Psychological Measurement, Vol. 48 No. 4, pp. 1075-1079.

Lee, C.H. and Bruvold, N.T. (2003), "Creating value for employees: investment in employee development", The International Journal of Human Resource Management, Vol. 14 No. 6, pp. 981-1000.

Lee, T.W., Mitchell, T.R., Sablynski, C.J., Burton, J.P. and Holtom, B.C. (2004), "The effects of job embeddedness on organizational citizenship, job performance, volitional absences, and voluntary turnover", Academy of Management Journal, Vol. 47 No. 5, pp. 711-722.

Li, J.J., Kim, W.G. and Zhao, X.R. (2017), "Multilevel model of management support and casino employee turnover intention”, Tourism Management, Vol. 59, pp. 193-204.

Liden, R.C. and Graen, G. (1980), "Generalizability of the vertical dyad linkage model of leadership", Academv of Management Journal, Vol. 23, pp. 451-465.

Lim, A.J.P., Loo, J.T.K. and Lee, P.H. (2017), "The impact of leadership on turnover intention: the mediating role of organizational commitment and job satisfaction", Journal of Applied Structural Equation Modeling, Vol. 1 No. 1, pp. 27-41.

Lu, L., Lu, A.C.C., Gursoy, D. and Neale, N.R. (2016), "Work engagement, job satisfaction, and turnover intentions: a comparison between supervisors and line-level employees", International Journal of Contemporary Hospitality Management, Vol. 28 No. 4, pp. 737-761.

Lucas, S. (2012), "How much does it cost companies to lose employees?", available at: www.cbsnews. com/8301-505125_162-57552899/howmuch-does-it-cost-companies-to-lose-employees

McGinley, S.P., Hanks, L. and Line, N.D. (2017), "Constraints to attracting new hotel workers: a study on industrial recruitment”, International Journal of Hospitalitv Management, Vol. 60, pp. 114-122.

Maertz, C.P. Jr and Campion, M.A. (1998), "25 years of voluntary turnover research: a review and critique", International Review of Industrial and Organizational Psychology, Vol. 13, pp. 49-81.

Martınez-Roman, J.A., Tamayo, J.A., Gamero, J. and Romero, J.E. (2015), "Innovativeness and business performances in tourism SMEs", Annals of Tourism Research, Vol. 54, pp. 118-135.

Masterson, S.S., Lewis, K., Goldman, B.M. and Taylor, M.S. (2000), "Integrating justice and social exchange: the differing effects of fair procedures and treatment on work relationships", The Academy of Management Journal, Vol. 43 No. 4, pp. 738-748.

Meyer, J.P. and Allen, N.J. (1997), "A three-component conceptualization of organizational commitment", Human Resource Management Review, Vol. 1 No. 1, pp. 61-89.

Mitchell, T.R., Holtom, B.C., Lee, T.W., Sablynski, C.J. and Erez, M. (2001), "Why people stay: using job embeddedness to predict voluntary turnover", Academy of Management Journal, Vol. 44 No. 6, pp. 1102-1121.

Morse, N.C. and Weiss, R.S. (1955), "The function and meaning of work and the job", American Sociological Review, Vol. 20 No. 2, pp. 191-198.

Mowday, R.T., Porter, L.W. and Steers, R.M. (1982), Organizational Linkage: The Psychology of Commitment, Absenteeism and Turnover, Academic Press, San Diego, CA.

Nunnally, J.C. and Bernstein, I.H. (1994), Psychometric Theory, 3rd ed., McGraw-Hill, New York, NY.

O'Fallon, J. (2014), "Powering Internal communication for employee advocacy: competitive advantage begins with employees who understand and want to share the electric co-op story", Yayımlanmamısô yüksek lisans tezi. ABD: University of Minnesotta.

Øgaard, T., Marnburg, E. and Larsen, S. (2008), "Perceptions of organizational structure in the hospitality industry: consequences for commitment, job satisfaction and perceived performance", Tourism Management, Vol. 29 No. 4, pp. 661-671.

Otaye, L. and Wong, W. (2014), "Mapping the contours of fairness - the impact of unfairness and leadership (in) action, on job satisfaction, turnover Intention and employer advocacy", Journal of Orqanizational Effectiveness: People and Performance, Vol. 1 No. 2, pp. 191-204, available at: http://dx. doi.org/10.1108/JOEPP-02-2014-0010. 
Pang, L., Kucukusta, D. and Chan, X. (2015), "Employee turnover intention in travel agencies: analysis of controllable and uncontrollable factors", International Journal of Tourism Research, Vol. 17 No. 6, pp. 577-590.

Pattie, M., Benson, G.S. and Baruch, Y. (2006), "Tuition reimbursement, perceived organizational support, and turnover intention among graduate business school students", Human Resource Development Quarterly, Vol. 17 No. 4, pp. 423-442.

Peltokorpi, V., Allen, D.G. and Froese, F. (2017), "Erratum: organizational embeddedness, turnover intentions, and voluntary turnover: the moderating effects of employee demographic characteristics and value orientations", Journal of Orqanizational Behavior, Vol. 38 No. 4, pp. 612-612.

Rahman, W. and Nas, Z. (2013), "Employee development and turnover intention: theory validation", European Journal of Training and Development, Vol. 37 No. 6, pp. 564-579.

Ramesh, A. and Gelfand, M. (2010), "Will they stay or will they go? The role of job embeddedness in predicting turnover in individualistic and collectivistic cultures", Journal of Applied Psychology, Vol. 95, pp. 807-823, doi: 10.1037/a0019464.

Rathi, N., Bhatnagar, D. and Mishra, S.K. (2013), "Effect of emotional labor on emotional exhaustion and work attitudes among hospitality employees in India", Journal of Human Resources in Hospitality and Tourism, Vol. 12 No. 3, pp. 273-290.

Robinson, R.N., Kralj, A., Solnet, D.J., Goh, E. and Callan, V. (2014), "Thinking job embeddedness not turnover: towards a better understanding of frontline hotel worker retention", International Journal of Hospitality Management, Vol. 36, pp. 101-109.

Roderick, D.I. and Deery, M. (1997), "Turnover culture in the hospitality industry", Human Resource Management Journal, Vol. 7 No. 4, pp. 71-82.

Roldán, J.L. and Sánchez-Franco, M.J. (2012), "Variance-based structural equation modeling: guidelines for using partial least squares", Research methodologies, innovations and philosophies in software systems enqineering and information systems, pp. 193-221.

Ruhanen, L., Scott, N., Ritchie, B. and Tkaczynski, A. (2010), "Governance: a review and synthesis of the literature", Tourism Review, Vol. 65 No. 4, pp. 4-16.

Ruiz, D.M., Gremler, D.D., Washburn, J.H. and Carrion, G.C. (2010), "Reframing customer value in a service-based paradigm: an evaluation of a formative measure in a multiindustry, cross-cultural context", in Vinzi, V.E., Chin, W.W., Henseler, J. and Wang, H. (Eds), Handbook of Partial Least Squares: Concepts, Methods, and Applications, Springer-Verlag, Heidelberg, pp. 535-566.

Rynes, S.L. (2004), "Where do we go from here?: imagining new roles for human resources", Journal of Management Inquiry, Vol. 13 No. 3, pp. 203-213, available at: http://dx.doi.org/10.1177/ 1056492604268202

Shore, L.M. and Tetrick, L.E. (1991), "A construct validity study of the survey of perceived organizational support", Journal of Applied Psychologv, Vol. 76 No. 5, pp. 637-643, available at: http://dx.doi.org/ 10.1037/0021-9010.76.5.637

Simons, T.L. and Hinkin, T.R. (2001), "The effect of employee turnover on hotel profits: a test across multiple hotels", The Cornell Hotel and Restaurant Administration Quarterly, Vol. 42 No. 4, pp. 65-69, available at: http://dx.doi.org/10.1016/S0010-8804(01)80046-X

Singh, V. and Sharma, S.K. (2016), "Analyzing the moderating effects of respondent type and experience on the fuel efficiency improvement in air transport using structural equation modeling", European TransportResearch Review, Vol. 8 No. 2, pp. 1-20.

Slatten, T. and Mehmetoglu, M. (2011), "Antecedents and effect of engaged frontline employees: a study from the hospitality industry", Managing Service Quality, Vol. 21 No. 1, pp. 88-107.

Smith, D.R., Holtom, B.C. and Mitchell, T.R. (2011), "Enhancing precision in the prediction of voluntary turnover and retirement", Journal of Vocational Behavior, Vol. 79 No. 1, pp. 290-302.

Takawira, N., Coetzee, M. and Schreuder, D. (2014), "Job embeddedness, work engagement and turnover intention of staff in a higher education institution: an exploratory study", SA Journal of Human Resource Management, Vol. 14 No. 1, pp. 524-534.

Tanova, C. and Holtom, B.C. (2008), "Using job embeddedness factors to explain voluntary turnover in four European countries", International Journal of Human Resource Management, Vol. 19 No. 9, pp. 1553-1568. 
Tsai, C.Y., Horng, J.S., Liu, C.H. and Hu, D.C. (2015), "Work environment and atmosphere: the role of organizational support in the creativity performance of tourism and hospitality organizations", International Journal of Hospitality Management, Vol. 46, pp. 26-35.

Tziner, A. and Birati, A. (1996), "Assensing employee turnover costs: a revised approach", Human Resource Management Review, Vol. 6 No. 2, pp. 113-122, available at: http://dx.doi.org/10.1016/S10534822(96)90015-7

Wadhwa, P. (2012), "The relationship between high involvement work systems, supervisory support, and organizational effectiveness: the role of employee experiences at work", PhD dissertation in Business, University of Kansas, 22 August.

Waldman, J.D., Kelly, F., Arora, S. and Smith, H.L. (2004), "The shocking cost of turnover in health care", Health Care. Management Review, Vol. 29 No. 1, pp. 2-7, available at: http://dx.doi.org/10.1097/ 00004010-200401000-00002

Walsh, K. and Taylor, M.S. (2007), "Developing in-house careers and retaining management talent: what hospitality professionals want from their jobs?", Cornell Hotel and Restaurant Administration Quarterly, Vol. 48 No. 2, pp. 163-182.

Wheeler, A.R., Harris, K.J. and Harvey, P. (2010), "Moderating and mediating the HRM effectivenessintent to turnover relationship: the roles of supervisors and job embeddedness", Journal of Managerial Issues, Vol. 22 No. 2, pp. 182-196.

Wickramasinghe, V. and Jayaweera, M. (2010), "Impact of career Plateau and supervisory support on career satisfaction: a study, in offshore outsourced IT firms in Sri Lanka", Career Development International, Vol. 15 No. 6, pp. 544-561.

Yeh, Y.P. (2014), "Exploring the ımpacts of employee advocacy on job satisfaction and organizational commitment: case of Taiwanese airlines", Journal of Air Transport Management, Vol. 36 No. 36, pp. 94100, available at: http://dx.doi.org/10.1016/j.jairtraman.2014.01.002

Zhou, X., Li, Q., Zhao, W. and Cai, H. (2003), “Embeddedness and contractual relationships in china's transitional economy", American Sociological Review, Vol. 68 No. 1, pp. 75-102.

\section{Further reading}

Biron, M. and Bamberger, P. (2012), "Aversive workplace conditions and absenteeism: taking referent group norms and supervisor support into account", Journal of Applied Psychologv, Vol. 97 No. 4, pp. 901-912.

Scovel, C.L. III (2012), Office of Inspector General, 2012, Aviation Industry Performance: A Review of the Aviation Industry, 2008-2011, US Department of Transportation, Controlled Correspondence No. 2012029, 24 September.

Huang, Y.H., Robertson, M.M., Lee, J., Rineer, J., Murphy, L.A., Garabet, A. and Dainoff, M.J. (2014), "Supervisory interpretation of safety climate versus employee safety climate perception: association with safety behavior and outcomes for lone workers", Transportation Research Part F: traffic Psychology and Behaviour, Vol. 26, pp. 348-360.

Karatepe, O.M. and Kilic, H. (2007), "Relationships of supervisor support and conflicts in the work-family interface with the selected job outcomes of frontline employees", Tourism Management, Vol. 28 No. 1, pp. 238-252.

Liden, R.C., Sparrowe, R.T. and Wayne, S.J. (1997), "Leader member exchange theory: the past and potential for the future", in Ferris, G.R. (Ed.), Research in Personnel and Human Resource Management, JAI Press, Greenwich, CT, pp. 47-119.

Stokburger-Sauer, N.E. (2011), "The relevance of visitors' nation Brand embeddedness and personality congruence for nation brand identification, visit intentions and advocacy", Tourism Management, Vol. 32 No. 6, pp. 1282-1289.

Zopiatis, A., Constanti, P. and Theocharous, A.L. (2014), "Job involvement, commitment, satisfaction and turnover: evidence from hotel employees in Cyprus", Tourism Management, Vol. 41, pp. 129-140. 
Table Al Descriptive statistics and normality tests of the constructs in the model

\begin{tabular}{|c|c|c|c|c|c|c|}
\hline Statistics & Mean & $S D$ & $\begin{array}{l}\text { Corrected item-total } \\
\text { correlation }\end{array}$ & Skewness & Kurtosis & $\begin{array}{l}\text { Supporting } \\
\text { literature }\end{array}$ \\
\hline Supervisor support (SUP) & & & & & & $\begin{array}{l}\text { Greenhaus et al. } \\
\text { (1990) }\end{array}$ \\
\hline $\begin{array}{l}\text { My supervisor takes the time to learn about my career } \\
\text { goals and aspirations (SUP1) }\end{array}$ & 3.9 & 0.804 & 0.594 & -0.594 & 0.685 & \\
\hline $\begin{array}{l}\text { My supervisor cares about whether or not I achieve my } \\
\text { career goals (SUP2) }\end{array}$ & 4.6 & 0.649 & 0.739 & -0.645 & 0.045 & \\
\hline $\begin{array}{l}\text { My supervisor gives me helpful feedback about my } \\
\text { performance (SUP3) }\end{array}$ & 4.3 & 0.849 & 0.604 & -0.445 & 0.74 & \\
\hline $\begin{array}{l}\text { My supervisor makes sure I get the credit when I } \\
\text { accomplish something substantial on the job (SUP4) } \\
\text { My supervisor assigns me special projects that increase } \\
\text { my visibility in the organisation (SUP5) }\end{array}$ & 3.7 & 0.856 & 0.778 & -0.626 & 0.428 & \\
\hline Employee advocacy (ADV) & & & & & & Yeh (2014) \\
\hline $\begin{array}{l}\text { The company attempts to represent the employees' best } \\
\text { interests (ADV1) }\end{array}$ & 3.8 & 0.842 & 0.748 & -0.548 & 0.759 & \\
\hline $\begin{array}{l}\text { The company provides its employees with tools to help } \\
\text { them solve their problems (ADV2) }\end{array}$ & 4.4 & 0.682 & 0.645 & -0.489 & 0.602 & \\
\hline $\begin{array}{l}\text { The company attempts to improve employee } \\
\text { satisfaction (ADV3) }\end{array}$ & 4.2 & 0.741 & 0.731 & -0.636 & 0.684 & \\
\hline $\begin{array}{l}\text { The company provides complete and open information } \\
\text { for employees (ADV4) }\end{array}$ & 4.7 & 0.589 & 0.721 & -0.589 & 0.617 & \\
\hline Job embeddedness (EMB) & & & & & & $\begin{array}{l}\text { Crossley et al. } \\
(2007)\end{array}$ \\
\hline I feel attached to this company (EMB1) & 4.8 & 0.859 & 0.765 & -0.503 & 0.355 & \\
\hline It would be difficult for me to leave this company (EMB2) & 3.9 & 0.914 & 0.803 & -0.691 & -0.263 & \\
\hline I am too caught up in this company to leave (EMB3) & 4.1 & 0.740 & 0.794 & -0.480 & -0.456 & \\
\hline I feel tied to this company (EMB4) & 4.2 & 0.738 & 0.483 & -0.578 & -0.526 & \\
\hline $\begin{array}{l}\text { I simply could not leave the company that I work for } \\
\text { (EMB5) } \\
\text { It would be easy for me to leave this company (EMB6) } \\
\text { I am tightly connected to this company (EMB7) }\end{array}$ & 4.1 & 0.478 & 0.490 & -0.434 & -0.564 & \\
\hline Organisational commitment (COM) & & & & & & $\begin{array}{l}\text { Crossley et al. } \\
(2007)\end{array}$ \\
\hline $\begin{array}{l}\text { This company has a great deal of personal meaning for } \\
\text { me (COM1) }\end{array}$ & 4.6 & 0.745 & 0.784 & -0.545 & 0.487 & \\
\hline $\begin{array}{l}\text { I would be happy to spend the rest of my career with this } \\
\text { company (COM2) }\end{array}$ & 3.7 & 0.859 & 0.832 & -0.690 & 0.833 & \\
\hline I feel like part of the family at my company (COM3) & 4.6 & 0.756 & 0.790 & -0.741 & 0.695 & \\
\hline I feel emotionally attached to this company (COM4) & 4.3 & 0.700 & 0.708 & -0.348 & 0.454 & \\
\hline $\begin{array}{l}\text { I feel a strong sense of belonging to my company } \\
\text { (COM5) }\end{array}$ & 5.4 & 0.543 & 0.540 & -0.304 & 0.564 & \\
\hline Intention to leave (INT) & & & & & & $\begin{array}{l}\text { Crossley et al. } \\
(2007)\end{array}$ \\
\hline $\begin{array}{l}\text { Within the next year, I intend to leave this profession } \\
\text { (INT1) }\end{array}$ & 4.6 & 0.765 & 0.769 & -0.490 & 0.174 & \\
\hline I plan to leave this company in the next little while (INT2) & 4.1 & 0.739 & 0.815 & -0.671 & 0.403 & \\
\hline I intend to leave this company soon (INT3) & 4.8 & 0.705 & 0.840 & -0.583 & 0.692 & \\
\hline I may leave this company before too long (INT4) & 3.9 & 0.589 & 0.458 & -0.289 & 0.478 & \\
\hline
\end{tabular}




\begin{abstract}
About the authors
Dr Yasser Moustafa Shehawy holds a PhD in Tourism and Hospitality from Helwan University, Egypt. He is Associate Professor at the Faculty of Tourism and Hospitality, University of Sadat City, Egypt. Also, Dr Shehawy currently acts as Assistant Professor at the Tourism Management Department, Faculty of Arts and Humanities, Jazan University, Kingdom of Saudi Arabia. His research interests are tourism management, rlectronic tourism marketing, information and communication technologies applications in tourism, sales promotion, tourism demand analysis, human resources and strategic management in tourism businesses, tourism planning, new trends in tourism, responsible or sustainable tourism development, airline strategies, and tourism events. Dr Shehawy has published several articles in journals such as the Tourism Management and International Journal of Heritage, Tourism, and Hospitality. Yasser Moustafa Shehawy is the corresponding author and can be contacted at: yasser.elshehawy@fth.usc.edu.eg
\end{abstract}

Ahmed Elbaz holds a PhD in Tourism and Hospitality from the Plymouth University, UK. He is Lecturer at the Faculty of Tourism and Hotels, University of Sadat City, Egypt. His research interests are tourism actor-networks, leadership in tourism, knowledge transfer, collaboration, environmental protection, sustainable livelihood, poverty reduction and sustainable tourism development, governance in developing countries and structural equation modelling (SEM) CB-SEM and PLS-SEM analysis in tourism. Dr Elbaz has published several articles in the Journal of Tourism Management and the International Journal of Knowledge Management. He currently acts as Assistant Professor in Business Administration Department, College of Applied Sciences, Salalah, Sultanate of Oman.

Gomaa M. Agag joined Plymouth Business School in March 2012. Before this, he worked in many academic institutions including Menofia University, Egypt, and Sadat City University, Egypt. Dr Agag's publications largely relate to electronic commerce, information systems in developing countries, social networking, international business and tourism management. Dr Agag has more than 15 journal and conference papers published or accepted for publication in Journal of Business Ethics, Journal of Travel Research, Journal of World Business and Journal of Internet Research. Dr Agag has also worked as a Consultant for some industrial companies in Egypt.

For instructions on how to order reprints of this article, please visit our website: www.emeraldgrouppublishing.com/licensing/reprints.htm Or contact us for further details: permissions@emeraldinsight.com 